Acta horticulturae et regiotecturae 1

Nitra, Slovaca Universitas Agriculturae Nitriae, 2014, p. 20-23

\title{
THE ADAPTIVE ABILITY OF CORNUS STOLONIFERA MICHX. 'KELSEYI' IN CHANGING ENVIRONMENT
}

\author{
Daniela BARTOŠOVÁ KRAJČOVIČOVÁ*, Viera ŠAJBIDOROVÁ \\ Slovak University of Agriculture in Nitra, Slovak Republic
}

\begin{abstract}
Water represents one of the limiting environmental factors having impact on all the processes in plants. Water stress is considered as the most significant cause of photosynthesis defects. Measuring fluorescence of chlorophyll a is one of the methods revealing defects in the photosynthetic aparatus. The examination has been carried out on the plants Cornus stolonifera Michx. 'KELSEYI' cultivated in two different irrigation regimes (a regime with $40 \%$ substrate saturation and a controlling regime with $60 \%$ substrate saturation). We have used a fluorometer HANSATECH FMS 1 to measure modulated fluorescence of chlorophyll a. A three-week period of measurement was set between June and August during two years of experiments (2011 and 2012). The selected chlorophyll fluorescence parameters $F_{v} / F_{m}$ - maximum quantum efficiency of PSII; TPSII - effective quantum yield of PSIl; $R_{f d}$ - chlorophyll fluorescence decrease ratio and NPQ - non-photochemical chlorophyll fluorescence quenching, proved to be insensitive to given water deficit. Cornus stolonifera Michx. 'KELSEY' appears to be a woody plant capable of water efficiency.
\end{abstract}

Keywords: Cornus stolonifera Michx. 'KELSEYI', water deficit, adaptation mechanisms

Conditions for existence of woody plants in the urban environment can be characterised as substantially changing in comparison with those in the natural habitat. As a result, it is crucial to carefully select the taxons capable of such adaptation. This is the reason why most of the experimental researches in the field of landscape architecture focus on research in stress factors having impact on plants in the urban environment. With regard to global warming, we perceive a growing lack of water accessible for plants. The purpose of our experiment is to verify the adaptation ability of a selected woody plant in the conditions of water stress in soil by using the method of chlorophyll fluorescence. It is obvious that the changes in PSII activities are caused by environmental stress (Repková, 2004) and as a result, the changes in the values of selected fluorescence parameters provide us with information on the reaction and adaptation abilities of plants in the conditons of environmental stress. Cornus stolonifera Michx. 'KELSEYI' belongs among the less demanding woody plants. It is mainly used as a groundcovering woody plant.

\section{Material and methods}

The investigated plant material (Cornus stolonifera Michx. 'KELSEYI') was obtained from a nursery (vegetatively reproduction). Specimen are approximately five to six years old. After the winter, the plants were replanted into the substrate Klasmann TS3 standard + clay $20 \mathrm{~kg} / \mathrm{m}^{3} ; \mathrm{pH} 5.5-6$ + fertilizer $1 \mathrm{~kg} / \mathrm{m}^{3}$ and acclimatised under the foiled coverage in standard conditions. After rooting, we set a different irrigation regime based upon the content of water in the substrate, which had been determined by a gravimetric method. A half of the plants were irrigated by $60 \%$ water capacity - a controlling variant and a half by $40 \%$ water capacity - a variant with a lower level of substrate saturation (in the pictures referred to as a stressed variant). A different irrigation regime was set through the whole vegetation period from June to September in the years 2011 and 2012. The specimen of the investigated cultivar were grown under a plastic tunnel.

Chlorophyll fluorescence was measured in three plants from each irrigation regime, i.e. three specimen from the variant "control" and other three from the variant with a lower level of substrate saturation. From each individual, three leaves were chosen totally - one from the lowest part, one from the middle and one from the top part of the plant. Chlorophyll fluorescence was carried out on the same three leaves in the morning hours. For measurement, we made use of a fluorometer HANSATECH FMS 1 and the software for data analysis MODFLUOR. We set a three-week period between June and August in course of the two-year experiment. In the year 2011, the measurements were carried out on June 23, July 14 and August 4, 2011 and in the year 2012, they were done on June 27, July 18 and August 8, 2012. Modulated fluorescence of chlorophyll a was triggered by measurement impulse on a shadowed sample of a leaf. Within 20 minutes, the plants got adapted to the dark, in the first year by way of leaf clips, in the second year the clips were replaced by a dark chamber. Modulated fluorescence of chlorophyll a is measured in accordance with a given measurement protocole. It is done through an optic cable with a thermic or a PAR sensor attached to a leaf clip post to the period of blackout. The measurement protocole modifies density and period of radiation of the sample by intense pulse light. The measurement was carried out in the radiation density of $895 \mu \mathrm{mol} \mathrm{m}^{-2} \mathrm{~s}^{-1}$ (the year 2011) and 1515 $\mu \mathrm{mol} \mathrm{m} \mathrm{m}^{-2} \mathrm{~s}^{-1}$ (the year 2012). As a result, we obtained the following fluorescence parameters: $F_{v} / F_{m}$ - maximum quantum efficiency of PSII; $\Phi$ PSII - effective quantum yield of PSIl; $R_{f d}$ - chlorophyll fluorescence decrease ratio and NPQ non-photochemical chlorophyll fluorescence quenching. The statistic significance of relations between the amount of irrigation ( $40 \%$ and $60 \%$ of substrate saturation) and the 
selected fluorescence parameters $-F_{v} / F_{m^{\prime}}$ ФPSII, $R_{f d}$ and NPQ, was observed by way of a statistic programme STAT GRAPHIC Centurion XV, a analysis of variance (ANOVA) and the Fisher LSD homogeneity test on the level of significance $\alpha 0.05$.

\section{Results and discussion}

In the years 2011 and 2012 we have tested sensitivity of the selected fluorescence parameters $-F_{v} / F_{m}$ - maximum quantum efficiency of PSII; $\Phi P S I I$ - effective quantum yield of PSII; $R_{f d}$ - chlorophyll fluorescence decrease ratio and NPQ non-photochemical chlorophyll fluorescence quenching to water deficit in the soil substrate. We discovered that the water deficit on $40 \%$ of substrate saturation has little impact on the selected fluorescence parameters, which proved low sensitivity or high adaptation ability of the selected woody plant to a given level of water deficit.

The main fluorescence parameter to be followed is the maximum quantum efficiency of PSII $\left(F_{v} / F_{m}\right)$, which represents the maximum photochemical capacity PSII (Tomeková, 2010). Björkman and Demming (1987) as well as Váňová and Kummerová (2006) consider such a parameter as the main marker of a plant's response to stress. Because of the environmental stress, its values fall under the level of 0.75 while the optimum is between 0.75 to 0.85 . When performing our own measurements, we found out that the values of maximum quantum efficiency of PSII $\left(F_{v} / F_{m}\right)$ have not changed depending upon the given irrigation regime (Figure 1). The parameter $F_{v} / F_{m}$ appeared to be insensitive towards water deficit in course of the two years, its average values ranged from 0.75 to 0.85 , which are typical for the plants in optimal conditions. Our findings on a weak reaction of $F_{v} / F_{m}$ to a relative low level of water deficit match the results obtained by Naumann et al. (2007) in case of Myrica cerifera L. a Phragmites australis (Cav.) Trin. ex Steud. On the contrary, the influence of water deficit on a drop in values of maximum quantum efficiency of PSII $\left(F_{v} / F_{m}\right)$ was proved by Gallé and Feller (2007) pri Fagus sylvatica $L^{m}$. and Bauerle et al. (2003) in case of Acer rubrum L. and Acer $\times$ freemanii E. Murray.

Another parameter to be carefully observed is the effective quantum yield of PSII (TPSII) which represents a real extract of active reaction centres of photosystem II when processing the absorbed solar energy (Schreiber, 2004). It is known that the values of DPSII fall due to environmental stress. In the first year of experiment we have observed a statistically-proven decrease in values of DPSII in the two irrigation regimes, which means that the plants have not perceived a difference in the amount of irrigation as a considerable limiting factor (Figure 2). Yet the period of duration of water deficit had a substantial impact on the decrease of ФPSII. In the second year, the values of ФPSII of the two regimes have not changed at all, not even in
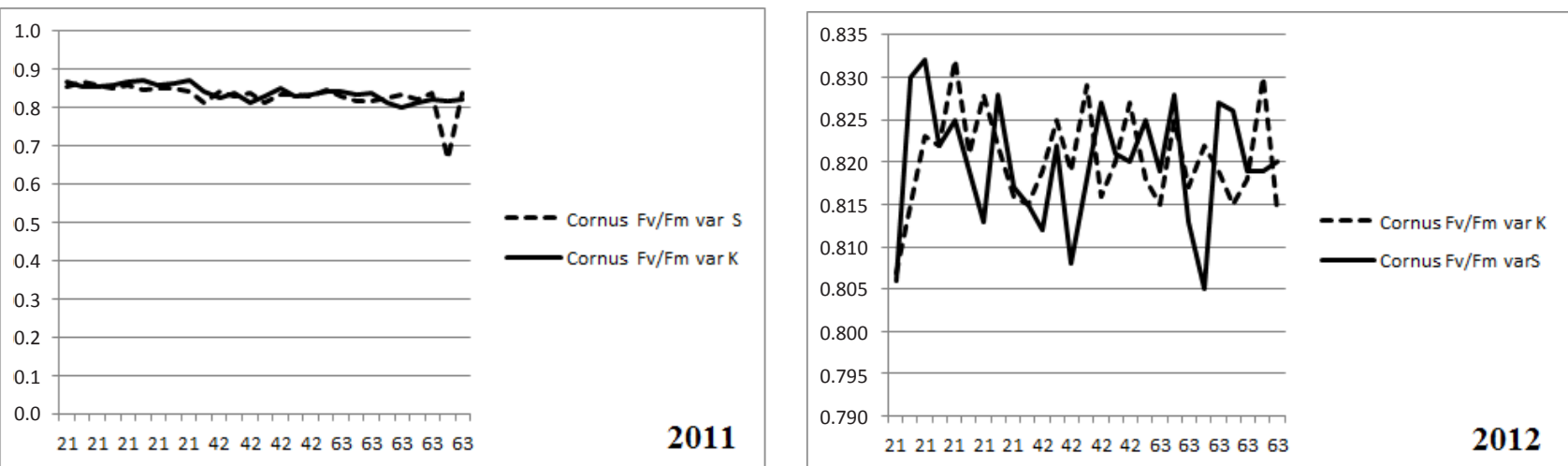

Figure 1 Changes in the values $F_{v} / F_{m}$ in particular years (the measurements carried out after 21, 41 and 63 days post to the initial measurement) var $S=$ stress variant - the variant with a lower level of substrate saturation, var $\mathrm{K}=$ controlling variant
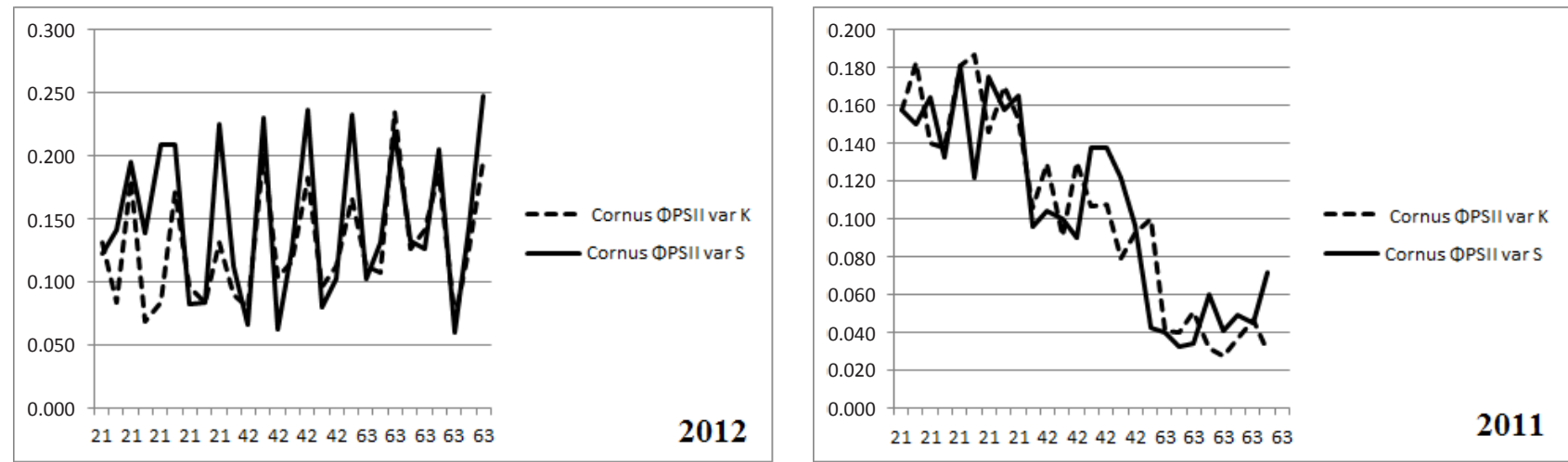

Figure 2 Changes in the values ФPSII in particular years (the measurements carried out after 21, 41 and 63 days post to the initial measurement) var $\mathrm{S}=$ stress variant - the variant with a lower level of substrate saturation, var $\mathrm{K}=$ controlling variant 

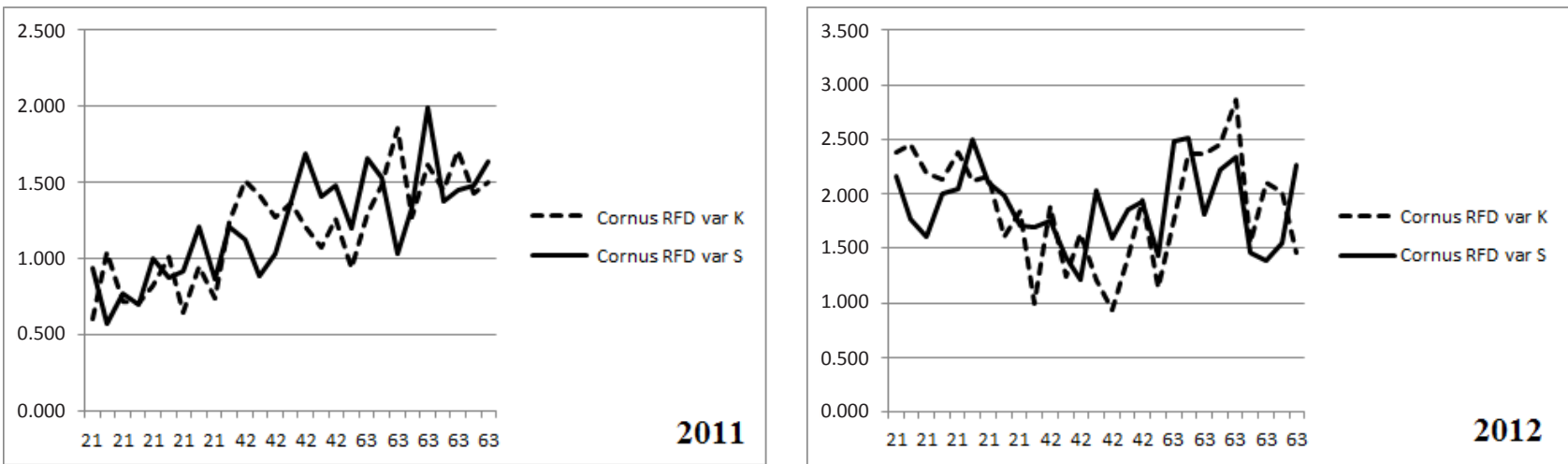

Figure 3 Changes in the values $R_{f d}$ in particular years (the measurements carried out after 21,41 and 63 days post to the initial measurement) var $\mathrm{S}=$ stress variant - the variant with a lower level of substrate saturation, var $\mathrm{K}=$ controlling variant
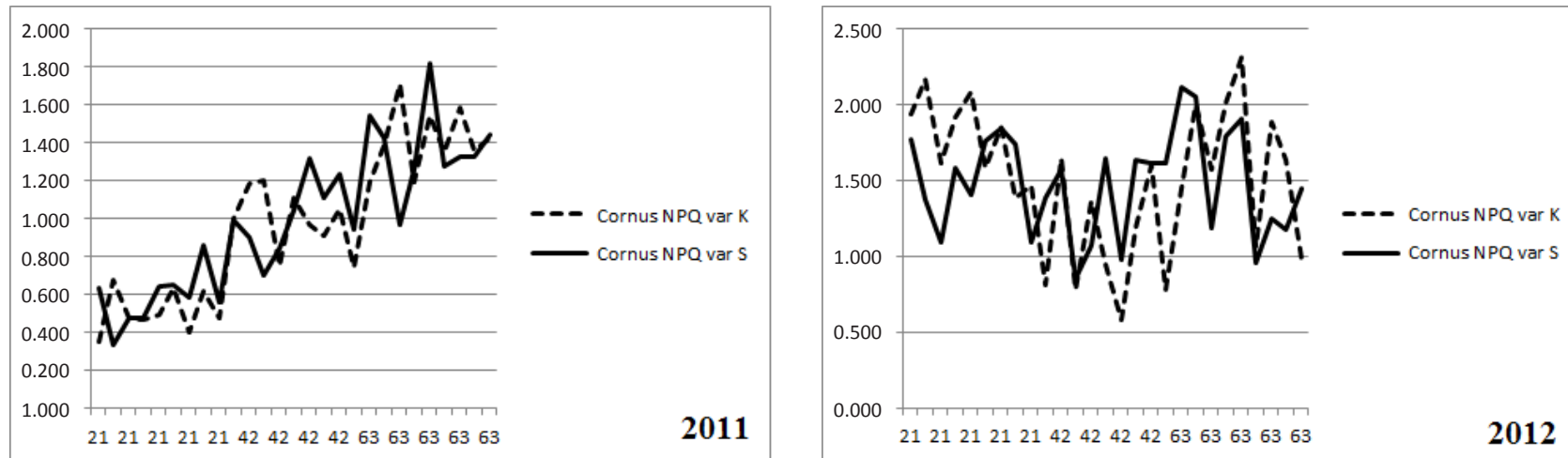

Figure 4 Changes in the values NPQ in particular years (the measurements carried out after 21, 41 and 63 days post to the initial measurement) var $\mathrm{S}=$ stress variant - the variant with a lower level of substrate saturation, var $\mathrm{K}=$ controlling variant

course of the period of observation. The results show low sensitivity of this parameter in a given level of water deficit. Thus, we are able to assume that the functionality PSII was not influenced. The similar results regarding a low reaction of TPSII on drought were obtained by Gallé and Feller (2007) in case of Fagus sylvatica L. and Munné-Bosch et al. (1999) in case of Rosmarinus officinalis L. On the contrary, Galle and Feller (2007) observed a decrease in DPSII in the conditions of water deficit in case of Quercus pubescens Willd., as well as was revealed by Peguero-Pina et al. (2008) in case of Quercus coccifera $\mathrm{L}$.

The following fluorescence parameter to be observed is a chlorophyll fluorescence decrease ratio $\left(R_{f f}\right)$. According to Lichtenthaler (2000), it represents a crucial parameter to react to environmental changes and thus it is considered as the index of vitality of the photosynthetic aparatus. Rfd represents a decrease in the intensity of fluorescence from the maximum $\left(F_{m}\right)$ to fluorescence in the steady state $\left(F_{s}\right) ; R_{f d}=F_{d} / F_{s}$ where $F_{d}=F_{m}-F_{s}$ (Hlízová, 2008). Under optimal conditions, we can observe higher values of $R_{f d}$ which reflect a higher photosynthetic activity and signalise the adaptation ability of woody plants (Lichtenhaler et al., 2005). In the opinion of Pukacki and Modrzyński (1998), plants under optimal conditions reach the values of $R_{f d} \geq 2.3$ and under the influence of abiotic factors the values fall. Lichtenhaler and Rinderle (1988) state that the values of $R_{f d} \geq 3$ represent high effectivity and speed of photosynthesis. Suboptimal conditions cause the interruption of photosynthetic process and they are characterised by a higher intensity of fluorescence and lower values of $R_{f d}$ (Lichtenthaler et al., 1997). In case of individuals of a selected woody plant, we have not observed any decrease in the values of $R_{f d}$ within the years of our experiment, the values $R_{f d}$ were increasing, which serves as a proof of a low value of water deficit in a particular taxon, i.e. its resistance against the given water content in the soil. The duration of water deficit substantially influenced the increase in values of $R_{f d^{*}}$ As a result, we can say that water deficit have not influenced the plants to such an extent that we might have reported a decrease in the values $R_{f d}$ due to a lower content of water in soil (Figure 3 ).

The last chlorophyll fluorescence parameter to be observed is non-photochemical chlorophyll fluorescence quenching $(N P Q)$. Absorbed solar radiation profits from the molecule of chlorophylle threefold. In optimal conditions, the highest amount of radiation is used for photosynthetic processes. Influence of environmental stress cause the most of solar radiation to be used for creation of fluorescence light or is dispersed into heat. The amount of dispersed heat (NPQ) is considered as a certain protection mechanism of a plant in an effort to remove excessive solar energy, which otherwise might have resulted in destructing the photosynthetic aparatus. The values of NPQ increase due to the influence of environmental stress.

In course of the experiment, we have revealed a considerable increase in the values of NPQ of the plants in each irrigation regime, which proves that they had not 
suffered from water deficit (Figure 4). Duration of water deficit had a substantial impact on the increase in the values of $N P Q$. The parameter $N P Q$ has not showed any difference between the regimes as described by Gallé and Feller (2007) in case of Fagus sylvatica L. Excessive dissipation of heat characterised by an increase in the values of NPQ was followed by Peguero-Pina et al. (2008) in case of Quercus coccifera L. and Niinemets and Kull (2001) in case of Tilia cordata Mill. and Populus tremula L.

\section{Summary}

In the years 2011 and 2012 we have tested the sensitivity of selected chlorophyll fluorescence parameters $\left(F_{v} / F_{m^{\prime}}\right.$ ФPSII, $R_{f d^{\prime}} N P Q$ ) to the lack of water in the soil substrate on the cultivar of woody plant Cornus stolonifera Michx. 'KELSEYI'. Significant effect of water deficit set at $40 \%$ saturation of the substrate to PSII has not been confirmed. We experimentally verified that the cultivar of woody plant is able to adapt to water scarcity in soil.

\section{Acknowledgment}

The research was supported by reseach grant projects VEGA 1/0426/09 "Plant adaptability and vitality as criteria of their utilization in urban environment" and VEGA 1/0246/13 "Strategies of the water utilization by xerophytic woody plants and perennials in urban conditions and landscape" from Slovak Grant Agency for Science.

\section{References}

BAUERLE, W. I. - DUDLEY, J. B. - GRIMES, L. W. 2003. Genotypic variability in photosynthesis, water use and light absorption among Red and Freeman Maple cultivars in response to drought stress. In: Journal of the American society for horticulture science, vol. 128, 2003. no. 3, p. 337-342.

BJÖRKMAN, O. - DEMMING, B. 1987. Photon yield of $\mathrm{O}_{2}$ evolution and chlorophyll fluorescence characteristics at $77 \mathrm{~K}$ among vascular plants of diverse origins. In: Planta, vol. 170, 1987, no. 4, p. 489-504. GALLÉ, A. - FELLER, U. 2007. Changes of photosynthetic traits in beech saplings (Fagus sylvatica) under severe drought stress and during recovery. In: Physiologia Plantarum, vol. 131, 2007. p. 412-421.

HLíZOVÁ, E. 2008. Využití fluorescence chlorofylu ke sledování fyziologického stavu vegetace. Bakalárska práca. Praha : Univerzita Karlova, 2008, 34 p.

LICHTENTHALER, H. K. 1997. Fluorescence imaging as a diagnostic tool for plant stress. In: Trends in plant science, vol. 2, 1997, no. 8, p. 316-320.
LICHTENTHALER, H. K. 2000. Detection of photosynthetic activity and water stress by imaging the red chlorophyll fluorescence. In: Plant Physiology and Biochemistry, vol. 38, 2000, no. 11, p. 889-895. LICHTENTHALER, H. K. - RINDERLE, U. 1988. Chlorophyll fluorescence signatures as vitality indicators in forest decline research. In: Applications of chlorophyll fluorescence. Kluwer Academic Publishers, 1988, p. 143-149.

LICHTENTHLALER, H. K. - BUSCHMANN, C. - KNAPP, M. 2005. How to correctly determine the different chlorophyll fluorescence parameters and the chlorophyll fluorescence decrease ratio R-Fd of leaves with the PAM fluorometer. In: Photosynthetica, vol. 43, 2005, p. 379-393.

MUNNÉ-BOSCH, S. - SCHWARZ, K. - ALEGRE, L. 1999. Enhanced formation of $\alpha$-tocopherol and highly oxidized abietane dipertenes in water-stressed Rosemary plants. In: Plant Physiology, vol. 121, 1999, p. 1047-1052.

NAUMANN, J. C. - YOUNG, D. R. - ANDERSON, J. E. 2007. Linking leaf chlorophyll fluorescence properties to physiological response for detection of salt and drought stress in coastal plant species. In: Physiologia plantarum, vol. 131, 2007, p. 422-433.

NIINEMETS, Ü. - KULL, O. 2001. Sensitivity of photosynthetic electron transport to photoinhibition in a temperate deciduos forest canopy: Photosystem II center openness, nono-radiative energy dissipation and excess irradiance under field conditions. In: Tree Physiology, vol. 21, 2001, p. 899-914.

PEGUERO-PINA, J. J. - MORALES, F. - FLEXAS, J. - GIL-PELEGRÍN, E. - MOYA, I. 2008. Photochemistry, remotely sensed physiological reflectance index and de-epoxidation state of the xanthophyll cycle in Quercus coccifera under intense drought. In: Oecologia, vol. 156, 2008, p. 1-11.

PUKACKI, P. M. - MODRZYŃSKI, J. 1988. The influence of ultraviolet-B radiaton on the growth, pigment production and chlorophyll fluorescence of Norway spruce seedlings. In: Acta Physiologiae Plantarum, vol. 20, 1988, no. 3, p. 245-250.

TOMEKOVÁ, B. 2010. Fenológia a fluorescencia chlorofylu jaseňa mannového rastúceho v Arboréte Borová hora. Diplomová práca. Zvolen : Technická univerzita, 2010. s. 97.

VÁŇOVÁ, L. - KUMMEROVÁ, M. 2006. Use of chlorophyll fluorescence for indication of stress in lower and higher plants. In: Vliv abiotických a biotických stresorů na vlastnosti rostlin 2006 : sborník přispěvků. Praha : Česká zemědelská univerzita, 2006. no. 1, p. 300. ISBN 80-213-1484-2.

\section{Contact address:}

doc. Ing. Daniela Bartošová Krajčovičová, PhD., Slovak University of Agriculture, Horticulture and Landscape Engineering Faculty, Department of Planting Design and Maintenance, Tulipánová 7, 949 76, Nitra, phone: 42137641 54 36, e-mail: daniela.krajcovicova@uniag.sk 